\title{
Math Teachers' Beliefs, Practices, and Belief Change in Implementing Problem Based Learning in Qatari Primary Governmental School
}

\author{
Ruba Samih Al Said ${ }^{1}$, Xiangyun Du ${ }^{1 *}$, Hadeel Abdelkarim H M ALKhatib ${ }^{1}$, \\ Michael Henry Romanowski ${ }^{1}$, Areej Isam Ibrahim Barham ${ }^{1}$ \\ ${ }^{1}$ College of Education, Qatar University, QATAR
}

Received 6 May 2018 • Revised 15 January 2019 • Accepted 15 January 2019

\begin{abstract}
This study explored math teachers' beliefs regarding their roles, practices and perceived change in implementing Problem-Based Learning in Qatar's primary government schools. Multiple sources of qualitative data were generated including metaphors, lesson plans and interviews with seventeen math teachers. Although teachers considered PBL as an effective method benefiting student learning and they demonstrated progress in changing their beliefs moving from subject to didactic dimension through PBL implementation, their practices remained partially aligned with their perceived belief changes. This discrepancy could be attributed to several encountered challenges, including teachers' insecurity and lack of confidence, difficulty in facilitating student collaboration, structural constraints, additional workload, and the lack of school and peer support. Results suggest the need for different types of "problems" and approaches such as more direct instruction, and higher feasibility in teachers' autonomy when implementing PBL in primary education.
\end{abstract}

Keywords: teachers' belief about their roles, teachers' belief change, math classrooms, Problem-Based Learning (PBL), Qatari primary governmental schools, metaphors

\section{INTRODUCTION}

Over the decades, Problem Based Learning (PBL) has been well-implemented as a learner-centered educational approach aiming to facilitate the development of $21^{\text {st }}$ century skills and competencies (Bell, 2010). This is accomplished through students' active roles in conducting research, integrating theory and practice, and applying "knowledge and skills to develop a viable solution to a defined problem" (Savery, 2006, p. 12). Over the decades, the effectiveness of PBL in higher educational settings has been well-documented (Norman \& Schmidt, 2016). Recent years demonstrate an increasing application of PBL in earlier stages of education, however, little is known about research surrounded K12 (Rico \& Ertmer, 2015). While a few studies provided positive evidence of the effectiveness of PBL on student performance in secondary STEM subjects, less is known regarding the impact of PBL in primary education (Merritt, Lee, Rillero, \& Kinach, 2017). Therefore, there is a need for additional research on PBL in the lower stages of K12 education and in particular when PBL is considered feasible and useful for young learners at this age group to develop reasoning and thinking skills in science and mathematics (Asghar et al., 2012; Merritt, Lee, Rillero, \& Kinach, 2017; Schettino, 2016).

Implementing PBL demands restructuring classroom practices that challenge teachers' traditional roles by encouraging them to facilitate independent and collaborative learning (Pecore, 2013). The teacher's understanding and acceptance of, and adjustment to new roles is crucial in adopting new instructional approaches such as PBL (Bakkenes, Vermunt, \& Wubbels, 2010; Pecore, 2013; Sabah \& Du, 2018). Particularly essential for conducting instructional innovation such as implementing PBL is teachers' belief, as an important factor framing one's teaching strategies and shaping behavior and practice (Mihaela \& Alina-Oana, 2015). Previous studies of PBL in higher

(C) 2019 by the authors; licensee Modestum Ltd., UK. This article is an open access article distributed under the terms and conditions of the Creative Commons Attribution License (http://creativecommons.org/licenses/by/4.0/). 《200750033@student.qu.edu.qa $\boldsymbol{\Delta x i a n g y u n @ q u . e d u . q a ~ ( * C o r r e s p o n d e n c e ) ~} \boldsymbol{\nabla}$ hadeela@qu.edu.qa \ichaelhr@qu.edu.qa $\bigotimes$ areejbarham@qu.edu.qa 


\section{Contribution of this paper to the literature}

- Although the effectiveness of PBL is well-researched, there is limited research concerning primary education and the implementation of PBL. More specifically, research addressing PBL implementation is limited in GCC contexts. This study contributes to this limitation by presenting findings that primary math teachers in Qatari governmental schools consider PBL as an effective method benefiting student learning. Teachers demonstrated progress in changing their beliefs moving from the subject to the didactic dimension through PBL implementation. Nevertheless, their practices remained partially aligned with their perceived belief changes.

- This discrepancy could be attributed to the encountered challenges when implementing PBL. including teachers' insecurity and lack of confidence, difficulty in facilitating student collaboration, structural constraints and additional workload, and lack of peer and school support. This study suggests that teachers in primary education, in particular, in Qatar, could be more influenced by the institutional constraints such as fulfilling curriculum standards and the consequences of potential failure. Nevertheless, PBL has feasibility in primary math education. However, scaffolding and direct instruction could be necessary at the early stages of education. Also, there is a need for different types of problems and approaches when applying PBL for lower grades in K12 education.

education highlighted the significance of changing the roles of university teachers implementing PBL (Kolmos, 2012; Moesby, 2004; Savin-Baden, 2003). These studies reported the challenges encountered such as embracing constructivist beliefs and lacking an understanding of PBL (Lee, Blackwell, Drake \& Moran, 2014) as all as a willingness to share the authority of content knowledge with students (Savin-Baden, 2003).

There is a need for additional knowledge about PBL implementation and its effectiveness on student learning in K12 education. However, it is useful to understand how teachers experience the process of changing their roles, their practices of implementation and how they perceive the changes needed. Therefore, this study aimed to fill the literature gap of teachers' belief of their roles and perceptions of their belief change in implementing PBL in STEM K12 education. Specifically, the study is embedded in the context of a top-down approach to the implementation of PBL in mathematics classrooms in Qatari primary governmental schools.

\section{THEORIES AND LITERATURE REVIEW}

\section{Problem Based Learning}

Taking its theoretical departure from a constructivism approach to learning, Problem Based Learning (PBL) methodology focuses on teachers' creating an environment where the students take responsibility of their own learning and gain knowledge in a real-world context (Savery, 2006). Students explore problems and use their knowledge to construct new learning and develop their skills (Ertmer \& Simons, 2006). PBL's focus on social learning requires students to work in groups that enable them to develop their communication, collaboration and problem-solving skills (Hmelo-Silver \& Barrows, 2006).

Prevailing literature documented PBL effectiveness on student motivation, learning performance and academic development in higher education (Hmelo-Silver, 2004; Hmelo-Silver \& Barrows, 2006; Kolmos, 2012; Norman \& Schmidt, 2016). While it is argued that research is needed for PBL in K12 education, specifically in in STEM fields, several studies reported learners' positive attitude towards science topics (Akınoğlu \& Tandoğan, 2007; Chen \& Chen, 2012). Other studies reported how PBL supports higher levels of critical thinking, independent work, motivation, engagement, and student understanding and problem-solving skills in STEM secondary education (Grant, 2011; Jerzembek \& Murphy, 2013; Liu, Bui, Chang, \& Lossman, 2012; Sungur \& Tekkaya, 2006; Tamim \& Grant, 2013). However, research in the effectiveness of PBL in primary education remains sparse. A recent systematic review of PBL effectiveness on student learning in K8 STEM education (Merritt, Lee, Rillero, \& Kinach, 2017) identified only three studies in primary education (Grade 1-6). These studies reported no clear patterns of whether or not or how PBL effects student performance (Drake \& Long, 2009; Karaçalli \& Korur, 2014; Leuchter, Saalbach, \& Hardy, 2014). Further studies are needed to explore the possibilities, conditions, barriers and effectiveness of PBL implementation in this stage of education.

Existing studies identified several challenges facing K12 teachers when implementing PBL. Facilitating collaboration was one of the first challenges (Ertmer \& Simons, 2006), that could lead to student resistance to PBL and group work (Gallagher \& Stepien, 1995). Another challenge included teachers adjusting to changing roles, for example in the aspects of designing and choosing topics for problem and projects (Grant, 2011; Tamin \& Grant, 2013. Finally, the need to dissolving the traditional hierarchy of mathematical authority was also a challenge (Schettino, 2016). These barriers could be related to both teachers' lack of understanding and prior experiences 
concerning PBL methodology (Tamin \& Grant, 2013; Thomas, 2000) and teachers' current pedagogical beliefs (Rico \& Ertmer, 2015). In addition, implementing PBL without adjusting assessment practices could generate confusion and disappointment for both teachers and students (Grant, 2011; Tamin \& Grant, 2013). Furthermore, the lack of resource support might generate barriers to successful change (Lee, Blackwell, Drake \& Moran, 2014). In the Middle Eastern context, students are reported to have strong uncertainty in taking responsibility of their own learning due to various traditions (Frambach, Driessen, Chan, \& Van der Vleuten, 2012).

\section{Teachers' Beliefs and Belief Change}

Beliefs can be defined as "mental constructs that represent the codifications of people's experiences and understandings" (Schoenfeld, 1998, p. 16). Beliefs are often related to practice, and in particular, teachers' beliefs have a strong effect and influence that shapes teachers' practice of applying strategies and organizing teaching activities (Burridge \& Carpenter, 2013; Mihaela \& Alina-Oana, 2015; Schoenfeld, 1998). Previous studies suggest a positive relation between teachers' beliefs and their role, classroom practice, instructional decision, the relationships they build with students and their work environment (Pajares, 1992; Wang \& Du, 2016). Teachers' beliefs regarding their roles are essential in their profession because they reflect their understanding of teaching and impacts lesson plans, classroom instruction and interactions with students (Ahonen, Pyhalto, Pietarinen, \& Soini, 2014). In addition, teachers' cultural backgrounds, individual experiences and contextual factors all contribute to the teachers' beliefs in their roles (Wang \& Du, 2016). Teachers who hold a strong belief in a teaching approach achieved a higher level of implementation (Burridge \& Carpenter, 2013). Implementing innovations and changes from outside without addressing the concerns of the teacher under the circumstances in which they work could lead to the failure (Korthagen, Kessels, Koster, Lagerwerf, \& Wubbels, 2001).

Individuals' beliefs are continually undergoing changes when faced with new perceptions from the environment that challenge assumptions (Pehkonen \& Törner, 1999), and when they compare, contrast and evaluate new experiences with prior experiences and perceptions (Pehkonen \& Törner, 1999). Belief change starts when teachers reflect, which produce in turn nuances and changes of behavior over time (Mihaela \& Alina-Oana, 2015). Teachers who are changing from a teacher-centered approach to a student-centered approach make choices based on the new beliefs and assumptions. For example, they reduce the time for lecturing and change their teaching role from information transmitter to learning facilitator (Fullan, 2014). This change process can be time costly and difficult for teachers to accept and adopt, therefore teachers must be supported by appropriate professional development activities (Salvin-Baden, 2003).

\section{Math Teachers' Beliefs about PBL Implementation}

PBL implementation in math classrooms requires teachers to embrace constructivist mathematical beliefs, that involve changes in the math educator's role. These roles include not only being an instructor that stresses skill mastery with expected abilities, but also both an educator orientated toward conceptual understanding with whole knowledge, and a facilitator who relies on positing and solving problems, encouraging team work, and applying formative assessment for learning (Novikasari, 2016). Implementing PBL requires teachers to identify and analyze students' needs in order to construct a learning environment where students feel free to interact with peers, to apply mathematical concepts to real-world issues, and to construct new knowledge using their previous knowledge (Tamim \& Grant, 2013). It can be challenging to practice the innovation successfully if teachers are not ready for these changes or lack motivation (Adelman \& Taylor, 2007; Lam, Cheng, \& Choy, 2010). To facilitate successful practice of PBL implementation, it is useful for teachers to understand and accept the change and believe that this change will be beneficial (Pecore, 2013). Accordingly, aiming for successful implementation, research attention is called for exploring teachers' role change and their perceptions of this change while implementing PBL (Rico \& Ertmer, 2015).

\section{CURRENT STUDY}

In Qatar, PBL remains a new phenomenon until recent years when the government began to facilitate educational change that supports new learning approaches shifting teacher-centered learning to student-centered learning enhancing student learning and teacher performance (Said, 2016). Starting in 2015, the Ministry of Education and Higher Education (MOEHE) announced a change initiative implementing Problem Based Learning in math classrooms in primary governmental schools, starting with a few schools selected as a pilot project. This study aimed to explore how math teachers in this pilot project experienced the first three year's change process how they understood and practiced PBL and what beliefs they held about their roles and potential changes over the three years' experience of implementing PBL. The following research questions were formulated: 


\begin{tabular}{|c|c|c|c|c|c|c|c|c|c|c|}
\hline Teacher & School & Gender & Nationality & Age & $\begin{array}{l}\text { Teaching } \\
\text { experience }\end{array}$ & $\begin{array}{l}\text { Educational } \\
\text { Level }\end{array}$ & $\begin{array}{l}\text { Teaching } \\
\text { grade }\end{array}$ & Metaphors & $\begin{array}{l}\text { Lesson } \\
\text { plans }\end{array}$ & Interview \\
\hline T1 & A & $\mathrm{F}$ & Egyptian & 31 & 8 & B. D. in Math & 3 & & & - \\
\hline T2 & A & $\mathrm{F}$ & Qatari & 37 & 14 & B. D. in Math & 4 & & & - \\
\hline T3 & A & $\mathrm{F}$ & Qatari & 46 & 24 & B. D. in Math & 4 & & & - \\
\hline T4 & A & $\mathrm{F}$ & Iraqi & 39 & 11 & B. D. in Math & 5 & & & $\gamma$ \\
\hline T5 & A & $\mathrm{F}$ & Egyptian & 37 & 14 & B. D. in Math & 6 & & & $\checkmark$ \\
\hline T6 & $\mathrm{C}$ & $\mathrm{F}$ & Jordanian & 32 & 9 & B. D. in Math & 7 & & & $\gamma$ \\
\hline T7 & A & $\mathrm{F}$ & Syrian & 30 & 9 & B. D. in Science & 1 & & & - \\
\hline T8 & $\mathrm{A}$ & $\mathrm{F}$ & Egyptian & 41 & 8 & B. D. in Math & 6 & & & $\checkmark$ \\
\hline T9 & B & $\mathrm{F}$ & Egyptian & 38 & 8 & B. D. in Math & 4 & & & - \\
\hline T10 & A & $\mathrm{F}$ & Jordanian & 50 & 20 & B. D. in Math & 5 & & & $\checkmark$ \\
\hline T11 & A & $\mathrm{F}$ & Egyptian & 45 & 13 & B. D. in Math & 2 & & & $\gamma$ \\
\hline T12 & A & $\mathrm{F}$ & Qatari & 42 & 16 & B. D. in Biology & 1 & & & - \\
\hline T13 & A & $\mathrm{F}$ & Palestinian & 37 & 8 & B. D. in Science & 2 & & & $\checkmark$ \\
\hline T14 & A & $\mathrm{F}$ & Sudanese & 46 & 12 & B. D. in Science & 1 & & $\checkmark$ & - \\
\hline T15 & B & $\mathrm{F}$ & Egyptian & 33 & 10 & B. D. in Math & 3 & & $\checkmark$ & - \\
\hline T16 & B & $\mathrm{F}$ & Egyptian & 34 & 15 & B. D. in Math & 3,4 & & $\checkmark$ & $\checkmark$ \\
\hline T17 & B & $\mathrm{F}$ & Egyptian & 29 & 4 & B. D. in Math & 6 & $\checkmark$ & $\checkmark$ & - \\
\hline
\end{tabular}

Figure 1. Information about the participants

1) In what ways do math teachers in Qatar perceive (or not) problem-based learning (PBL) as a useful instructional approach in primary classrooms?

2) How do the math teachers practice PBL?

3) How do the math teachers perceive their teaching roles after three years' implementing PBL? Have they experienced any changes in their perceptions?

4) From the teacher's perspective, what are the challenges in implementing PBL?

\section{RESEARCH METHOD}

\section{Participants}

All 21 math teachers involved in the overall PBL implementation pilot project from the three primary governmental schools (two were schools for girls and one was for boys) were invited to participate in this study. Among them 17 teachers responded to the metaphor survey and 15 teachers provided their lesson plans before and after they implemented PBL. Eight teachers participated in the interviews.

All participants were female teachers and Native Arabic speakers with 13 holding bachelor's degrees in mathematics and four with bachelor's degree in biology or science. The participants' teaching experience ranged between 4-24 years, among them 16 had more than eight years' teaching experiences. The letter " $\mathrm{T}$ " was used for coding teachers as participants volunteering preferred anonymity in the study. See Figure $\mathbf{1}$ for detailed information about the participants.

\section{Research Design and Data Generation}

A qualitative research was designed because it uncovers "identities, experiences, beliefs and orientations" (Talmy, 2010, p. 111). Multiple sources of data were generated including metaphor, lesson plan, and interviews. There were three phases of data generation in this study, 1) metaphors, 2) lesson plans and 3) participant interviews.

Metaphors are used to transfer the features of one thing to another by considering the similarities between these two things (Lakoff \& Johnson, 1980). Teachers' metaphors can be used as an indirect way to understand teachers' beliefs concerning teaching, learning and their role, which may be implicit or hidden (Löfström \& Poom-Valickis, 2013). To explore teachers' beliefs, in phase one of the study "metaphors," participants were asked to provide metaphors through a survey. For example, the survey requested participants to provide two metaphors delivering a brief clarification of their metaphor by completing the statement, "Being a teacher is like...because...". The first was to describe the teacher's role prior to PBL implementation and the second was to describe the teacher's role after PBL implementation. 
A lesson plan, in the form of a combination guide, resource, and historical document, is a useful tool that reflects teaching philosophy, student population, textbooks, and goals for students (Jensen, 2001). Teachers holding a constructivist belief design instructional activities that focus on students as active participants and emphasizes facilitating student inquiry (Laius, Kask \& Rannimaee, 2009). To explore how teachers practice PBL, in phase two of the study 'lesson plans," participant teachers' lesson plans including prior to the implementation of PBL and after PBL has been implemented for three years were collected and analyzed, how their beliefs framed their teaching practices.

Interviews are useful tools to capture teachers' thinking, and beliefs through the conversations than other data collection tools (Patton, 1990). In phase three of the study "participant interviews,", participant teachers were interviewed to gain a deeper understanding of their beliefs, experiences, opinions and feelings (Kvale \& Brinkmann, 2009). The comparison between metaphor results and lesson plans analysis brought insights for the development of interview questions, which were focused on their experiences, perceptions of PBL implementation, belief changes, and current practices and challenges. All eight interviews took place in the teachers' schools each lasting 30-60 minutes. The interviews were conducted in Arabic and audio recorded, transcribed and translated into English for content analysis.

\section{Data Analysis}

An integrated approach was employed for data analysis comparing multiple sources of qualitative data, combining both a thematic approach (Kvale \& Brinkmann, 2009) and theory driven approach (Namey, Guest, Thairu, \& Johnson, 2008). For the metaphor analysis, a theory-driven deductive content analysis was applied using the categorization created by Löfström, Poom-Valickis, and Hannula (2011). The lesson plans were first analyzed following the eight-step guidelines of the PBL teaching design framework $(\mathrm{Du}, 2012)$ before patterns were summarized. Interview transcripts were analyzed with emerging themes and comparing to literature.

\section{FINDINGS}

The following section introduces findings from participants' developed metaphors, an analysis of their PBL lesson plans and responses from interviews. These findings are presented by addressing each research question individually followed by a discussion.

\section{How do Math Teachers in Qatar Primary Governmental Schools Perceive PBL as a Useful Method?}

\section{Improvement in mathematics learning skills}

All of the eight interviewed teachers found PBL useful to improve students' mathematics problem-solving and deep learning levels. Six of them (T5, T6, T8, T11, T13, T16) mentioned that working on problem solving requires critical thinking and analytical skills. Moreover, two teachers (T4 and T10) mentioned that students gained deeper understanding through reading questions and relating to the problem inquiry process. As one teacher stated, "This method gives more space for thinking and analyzing mathematical problems. It gives them a chance to think deeply and critically to solve different math problems." (T10).

In addition, interviewed teachers reported their observation of improved students' independence in learning witnessing students taking more responsibility for their own learning. Four teachers (T4, T6, T10, T11) mentioned that their students become more independent in using their knowledge and skills to solve problems. Five teachers (T5, T8, T10, T13, T16) identified improved academic performance from their students. All eight teachers believed that not only high achievement, but also low achievement students demonstrated their ability to work independently in a PBL process. In particular, for the low achievement students, the PBL process helped them gain confidence to engage in the inquiry process. "In problem-based learning, sometimes high achievers surprise me with new ways I have not even thought of, even low achieving students find a solving strategy that suits their abilities...sometimes they understand the explanation from peer students better" (T13).

\section{Motivation and engagement}

Motivation is one of the most important drivers to learn mathematics, otherwise it could become boring and over abstract. Low learning motivation in primary education in Qatar has been reported as a critical issue. All eight teachers who were interviewed indicated there is a low learning motivation among students. All eight teachers believed that the PBL method was highly useful in this matter and reported students' increased motivation and engagement to learning as a visible improvement in a PBL environment. In particular, four teachers mentioned 
how PBL motivated and encouraged low achieving students. For example, one teacher (T5) stated, "I had some weak students... they all gained more motivation, it made them more willing to solve additional problems to try their new skills out". (T5).

\section{Collaborative learning}

Students' development in functioning and communicating in a group setting was also highlighted as a major benefit from PBL in this study. These teachers explained their experience with collaboration in two aspects. First, there were three teachers (T6, T10, T11) who discussed "student-teacher" collaboration, reflecting a change in the teacher and students' role where teachers reduced their control of dominance over the class and students began to move away from being passive receivers of knowledge. For example, one of the three teachers (T 11) stated, "We both work together..... I no longer give out rules for them to memorize and use. We are all looking for solutions." (T11).

Five teachers addressed "student-student" collaboration (T4, T5, T8, T10, T13, T16). Their students felt responsible for helping each other and accepted their peers' opinions. One teacher stated, "My students' behavior changed. They are listening to each other and are trying different suggestions from their peers. They like to share ideas and solutions." (T8).

\section{Addressing individual differences}

One of the major challenges for teachers in the government schools is the students' different perspectives and methods of approaching mathematical problems that reflect their different abilities, background, and environment. Teachers suggested that through PBL, every student can choose a solving strategy he or she understands. Through PBL, every student has space to work on a problem that is suitable to their own speed and preference and find strategies that work for each individual. In particular, two participants mentioned how team work provide support from not only from teachers but also from others students and this proved helpful to low achieving students. One teacher mentioned, "This generation is different. I teach students from different Arab countries. They need different strategies to match their learning styles. We need to adapt to this. I found student-centered learning more suitable for them than the traditional one." (T16).

\section{How do the Math Teachers Practice PBL?}

Data analysis from teachers' interviews and lesson plans provided an overview of how they implemented PBL. The 17 teachers' lesson plans were analyzed respectively by pre- PBL implementation and current practice, following the eight steps of the guideline of PBL teaching design proposed by Du (2012). Figure 2 shows the results of the teachers' PBL practice indicating whether their lesson plans include the eight steps or not.

Lesson plan samples prior to PBL were found to be nearly identical, despite school differences. This could be due to the fact that all schools must follow the MOEHE requests and both the guidelines of the textbook and the teacher's book. Comparing lesson plan analysis results with interview transcripts, two general patterns of PBL practices were summarized, mainly by frequency counting of addressing each step of the procedure. The two patterns are described as below.

First, in four of the eight suggested steps, all collected lesson plans (except T2 and T10 missing prior PBL examples) included steps 1,3,4, and 8 in both prior and post PBL implementation. Nevertheless, differences of priorities and focuses were observed between prior and post PBL lesson plans in these aspects.

Regarding step 1, all lesson plans prior to PBL addressed the context, focusing on classroom environment and physical facilities. While in the PBL lesson plans, all teachers elaborated the strategies of choosing specific mathematics problems considering their connection to the social contexts that would make sense to Arabic students. For example, one teacher utilized the topic of camel racing, asking students to calculate the speed of camels when given the distance and time using locations in Qatar.

Concerning steps three "Designing Teaching Activity" and four "Encouraging Teamwork," the prior to PBL lesson plans structured class activities following the MOEHE request and teacher book guidelines. No variation was expected and observed in the samples. PBL lesson plans identified a range of activities. Three teachers (T1, T4, and T5) included problem-solving strategies, involved higher thinking questions with no model answers, and expected students to work independently. Students then shared solutions with their team and presented a few options from team-based results to discuss with teacher. The teacher would analyze various options for the solutions with the team. A significant amount of time is planned for student-student interaction in team. 12 among the 17 teachers (T3, T6, T7, T8, T10, T11, T12, T13, T14, T15, T16, \& T17) designed their PBL activities combining students working independently and discussing with peers, before instruction was provided by the teachers with a model answer at the end. Two teachers (T2 and T9) used textbook questions with neither supporting activities, nor higher thinking questions and team work. 
EURASIA J Math Sci and Tech Ed

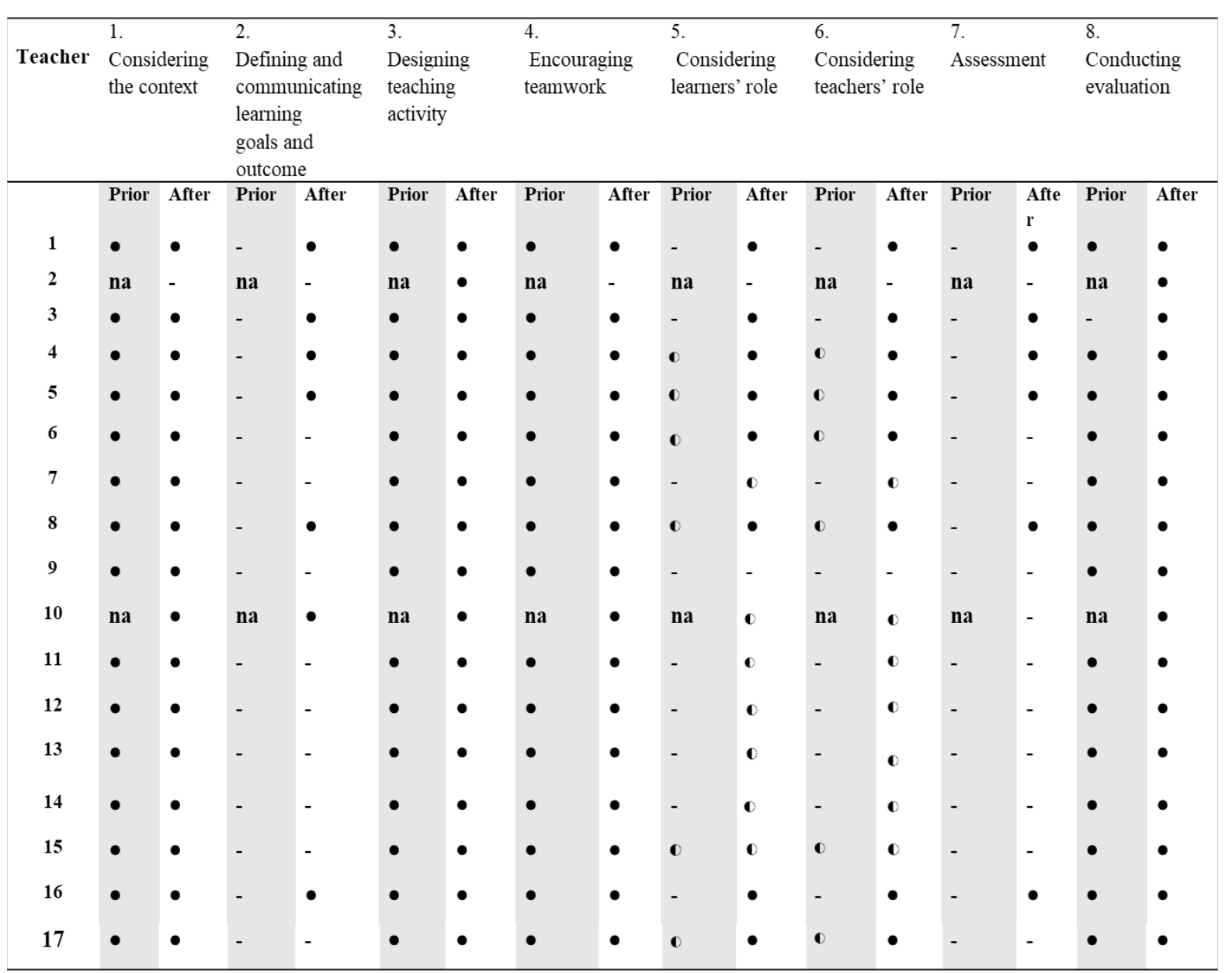

Figure 2. Teachers' lesson plan analysis PRIOR and three years' AFTER PBL implementation

(na: not available, $\bullet$ : existed, $\quad$ : partially existed, $\quad-$ : not existed)

Evaluation forms, as part of the lesson plan documents, were highly emphasized in both prior and after lesson plans by all the 17 teachers, because these are required by the MOEHE, as they explained. The evaluation forms, prior to PBL implementation were mainly focused on evaluating whether the textbook objectives were addressed or not. The lesson plans for PBL implementation specified questions about students' abilities and how the group was conducted In addition, evidence from the students' daily work was collected and reported on a form titled classroom record, including their reactions, achievements and feedback in the problem-solving process.

Second, the other four of the eight proposed steps - Step 2 "Defining and communicating learning goals and outcome", 5 "Considering Learners' role," 6 "Considering Teachers' Role," and 7 "Assessment" - were not addressed in the lesson plans prior to PBL but were given attention at various levels in the PBL lesson plans. This is mainly because they were not required, and assessment was defined by MOEHE as following the required textbooks.

Assorted ways were observed in the PBL lesson plans. Four teachers (T1, T3, T4 and T5) planned to invite students to define the goals through classroom discussion with the support of the teacher. Two teachers (T10 and T16) defined the goals in the lesson plans and structured time to communication these goals with students. Eleven teachers (T2, T6, T7, T8, T9, T10, T11, T12, T13, T14, T15, and T17) defined the learning goals but did not plan time and activities to communicate the goals with their students. The reasons provided during interviews included limited class time, large class size and pressure to finish the requested schedule.

Six teachers (T1, T3, T4, T5, T16, and T17) stated in their lesson plans that students should play the main role in class with no direction from the teacher. Students should provide various solutions to PBL problems. In addition, teachers should play the role of evaluator and supporter only when help is needed. There were nine teachers (T6, $\mathrm{T} 7, \mathrm{~T} 8, \mathrm{~T} 10, \mathrm{~T} 11, \mathrm{~T} 12, \mathrm{~T} 13, \mathrm{~T} 14$, and T15) that described the expected roles through the activity design, mentioning the plan of encouraging the students to question one another, clarify, compare and discuss before teacher modeling the correct solving strategy. However, they did not clearly define the roles of the teacher and students in PBL lesson plans. During interviews, teachers reported that this plan could only be partially implemented because students 
Table 1. Teachers' metaphors prior to and after PBL

\begin{tabular}{|c|c|c|c|c|c|c|c|}
\hline $\begin{array}{l}\begin{array}{l}\text { Group of } \\
\text { teachers }\end{array} \\
\end{array}$ & $\begin{array}{c}\text { Subject matter } \\
\text { expertise }\end{array}$ & $\begin{array}{c}\text { Didactical } \\
\text { expert }\end{array}$ & $\begin{array}{c}\text { Pedagogical } \\
\text { expert }\end{array}$ & $\begin{array}{c}\begin{array}{c}\text { Self-referential } \\
\text { expert }\end{array} \\
\end{array}$ & $\begin{array}{c}\text { Contextual } \\
\text { expert }\end{array}$ & $\begin{array}{l}\text { Hybrid } \\
\text { expert }\end{array}$ & Total \\
\hline $\begin{array}{c}\text { No. of } \\
\text { metaphors } \\
\text { prior PBL }\end{array}$ & $\begin{array}{c}9 \\
(53 \%)\end{array}$ & $\begin{array}{c}\mathbf{2} \\
(11.8 \%)\end{array}$ & $\begin{array}{c}\mathbf{3} \\
(17.6 \%)\end{array}$ & $\begin{array}{c}\mathbf{0} \\
(0 \%)\end{array}$ & $\begin{array}{c}\mathbf{0} \\
(0 \%)\end{array}$ & $\begin{array}{c}\mathbf{2} \\
(11.8 \%)\end{array}$ & $\begin{array}{c}17 \\
(100 \%)\end{array}$ \\
\hline $\begin{array}{c}\text { No. of } \\
\text { metaphors } \\
\text { After PBL }\end{array}$ & $\begin{array}{c}\mathbf{0} \\
(0 \%)\end{array}$ & $\begin{array}{c}12 \\
(70.6 \%)\end{array}$ & $\begin{array}{c}\mathbf{3} \\
(17.6 \%)\end{array}$ & $\begin{array}{c}1 \\
(5.9 \%)\end{array}$ & $\begin{array}{c}\mathbf{0} \\
(0 \%)\end{array}$ & $\begin{array}{c}1 \\
(5.9 \%)\end{array}$ & $\begin{array}{c}17 \\
(100 \%)\end{array}$ \\
\hline
\end{tabular}

needed more guidance than expected. Two teachers (T2 and T 9) did not address the roles of teachers and students in their PBL lesson plan explaining in the interview that students should be directed by the teacher from the beginning of the exercise and should be provided with model answers.

Concerning Step 8 "assessment," five PBL lesson plans (T1, T3, T4, T5, and T16) included plans to communicate with students regarding how they would be assessed. The plans even encouraged students to identify what they already knew and what they needed to learn in order to solve the main problem. Other teachers did not show any considerations regarding involving students in the assessment.

\section{How do the Math Teachers Perceive their Teaching Roles after Three Years' Implementing PBL? Have they Experienced any Changes in their Perceptions?}

Based on previous work, Lofström, Poom-Valickis, and Hannula (2011) summarized six metaphors of teacher identity; 1) The teacher as a subject matter expert who possesses deep knowledge and acts as knowledge transmitters to the learners; 2) The teacher as a didactic expert who facilitates students' understanding and who is trained in the teaching and learning process; 3) The teacher as a pedagogical expert who nurtures student values and morals; 4) The teacher as a self-referential metaphor that refers to the teacher's characteristics without considering his or her role as a teacher; 5) The teacher as a contextual metaphor referring to the characteristics of his or her work environment; 6) The teacher as a hybrid including elements of more than one of the above categories. Metaphors collected from the 17 teachers were analyzed based on these six categories as illustrated in Table 1. Researchers in this study individually coded and categorized the metaphors then compared results. If their results varied, the metaphors were re-examined until the researchers agreed on the appropriate categorization.

As Table 1 illustrated, four of the six metaphors (except self-referential and contextual experts) categories were addressed in the prior PBL survey, and four metaphor categories were addressed in after PBL implementation survey (except for subject matter and contextual experts). There was a noticeable shift in teachers' metaphors from the subject to didactical role after PBL implementation (from 9 to 0 for subject experts and 2 to 12 for didactical experts). Prior to PBL implementation, subject expert was the most frequent metaphor prior PBL implementation. Several teachers mentioned this stating, "The teacher is like a machine because they always work and plan for teaching, provide their students with knowledge in all circumstances without getting tired." (T10), "The teacher is like a prompter because they are at the core of learning process, and the source of information for students." (T4). After PBL, there were no teachers who addressed this category.

After three years of PBL implementation, didactics expert was the most commonly used metaphor. The number increased from two prior to PBL to twelve metaphors after PBL. Teachers mostly described math teachers as facilitators who help their students to learn and understand mathematics and enable the discovery of the new mathematical concepts. They also emphasize a more constructivist view of teaching and learning as well as the students' active role in the learning process. For instance, one of the teachers emphasized the importance of facilitating students' learning by guiding them to discover and understand mathematics described math teachers as a compass. The following comments demonstrate this shift in teachers' thinking.

"The teacher is like a lighthouse: They guide the students to reach learning goals and lightning for them the path for reaching the learning goals." (T5)

"The teacher is like a compass. They help the students to find their direction. They listen to their students. The students are the heart of the learning process". (T6)

"The teacher is like an electricity generator: They help students carry on their way on bringing light to new information." (T12)

"The teacher is like the gear of a machine. Teachers are flexible; they build their expectations according to the students' levels, giving students the chance to say what they think and to conclude new information from their previous knowledge. They facilitate higher thinking skills in analysing and evaluating their work." (T16)

In addition, there were three teachers that provided a description of the pedagogical expert for both phases. They emphasized caring and kindness as a teacher's main role. For example, one teacher stated, 
"The teacher is like a tree: He give shade to others, provide students with the fruits of knowledge and treat them all with kindness." (T7)

There were minor changes that occurred in the self-referential and hybrid groups. No metaphors were represented in the category of self-referential expert prior to PBL and one teacher used it after PBL implementation stating, "The teacher is like the whole system. They do everything. They teach, raise, heal, provide basis, build and explain." (T13). Finally, two teachers used hybrid metaphors prior to PBL and one teacher after PBL. "The teacher is like a blender: They blend between instructing, dictating, and knowledge providing. They have a great role in the learning process." (T6)

\section{Teacher's Perspective: The Challenges in Implementing PBL?}

Interview analysis identified a list of challenges perceived by the teachers regarding the implementation PBL. These were categorized into the four following themes; the lack of security and self-confidence; the difficulty in facilitating student collaboration, the lack of teacher collaboration and the extra workload created by the demand to achieve the regular curriculum standards.

First, the lack of security and self-confidence. All interviewed teachers mentioned their nervous feelings during the implementation process. They indicated worrying about whether students would accept the new approach or not and how it would affect the classroom. Five teachers explained that this concern was because they had no prior experiences and worried whether any mistake or failure would put their jobs at risk.

Second, teachers expressed some difficulty in facilitating student collaboration. Although all teachers mentioned the benefits of collaboration in learning mathematics, facilitating the students to work together remained a challenge for all teachers. More specifically, four teachers explained that one of the reasons could be because of the students' diverse cultural backgrounds that made it difficult to collaborate. For example, one teacher (T16) stated, "they think differently because of their backgrounds are different, it takes time for them to explain to each other." There were five teachers that believed the lack of prior experiences with collaboration was a challenge for students. Three teachers pointed to the age of the students and the Qatari culture as the reasons, as one explained "It is challenging with young girls to talk in front of their peers. The girls in this country are too shy." (T3).

Third, lack of teacher collaboration. Although teachers were encouraged to develop collaborative lesson plans, and they individually wished to share experiences and gain support from other teachers. All teachers reported that they found it hard to collaborate. One reason was there was lack of time and opportunities to communicate with each other and share experiences within school work hours. Another reason was peer teacher resistance. Half of the teachers mentioned that some their peer teachers did not accept the change strategy and participated in the PBL implementation only because of the the top-down decision. Those who were resistant did not believe in the benefits of PBL and expressed negative attitudes, which made the daily practice difficult for those who held positive attitudes, as one teacher stated, "Not all teachers accepted this method because it is quite new to them. When some do not accept PBL, it makes it more challenging for us" (T4). Hence, they often felt "alone and lonely" within each school.

Fourth, all interviewed teachers explained that they had to achieve the regular curriculum standards and this created an extra workload. They considered this the main challenge to PBL implementation. As one said, "The quantity of curriculum standard to be covered is the biggest obstacle that my students and I face." (T8). This challenge also included the number of required questions to be covered from the students' book in each class and the model answer it presented for students to follow. As a teacher explained, "The students' book is too crowded with information and the questions are hard to fit in tight timeframes." (T11). Succeeding this issue was time limitations. All teachers reported that limited time was provided for preparation and delivery of the PBL process. They indicated that students needed time to develop skills for PBL and also needed sufficient time to discuss the mathematical problems in the class. Also, teachers need time to prepare for lesson plans and develop new materials for PBL. Teachers felt they could not meet the required standards because of the time needed to solve and discuss the problem when using the PBL approach. For example one mentioned "We realized that PBL is time consuming. You know how hard it is for the teacher to control a large number of students in class. We also feel pressured with the workload." (T4)

\section{DISCUSSION AND CONCLUSION}

Concerning how teachers perceive PBL and the implementation, teacher participants expressed four themes of benefits that held significant value for learners. Among these themes, three aligned with previous studies addressing PBL advantages perceived by K12 teachers concerning improving mathematical learning skills such as problem solving, critical and high level thinking, motivation and engagement (Dole, Bloom, \& Doss, 2017; Grant, 2011; Jerzembek \& Murphy, 2013; Liu, Bui, Chang, \& Lossman, 2012; Sungur \& Tekkaya, 2006; Tamim \& Grant, 2013; Wong \& Day, 2009). These results also demosntrated that PBL allowed teachers to take advantage of the power of social interaction to achieve learning goals (Dole, Bloom, \& Doss, 2017; Tamim \& Grant, 2013). These 
perceptions echoed university teachers' experiences of PBL implementation (Gallagher \& Gallagher, 2013; Kazemi \& Ghoraishi, 2012; Lee, Blackwell, Drake \& Moran, 2014; Roh, 2003). Previous studies on PBL in higher education reported university teachers' resistance to the belief that PBL would benefit student learning in subject knowledge, in particular regarding science fundamental contents (Kolmos, 2012, Moesby, 2004). In comparison, the primary math teachers demonstrated more positive perceptions and attitudes towards the PBL impact on student learning in mathematical content knowledge. An additional category of perceived benefit identified by teachers in this study is that PBL addresses individual differences, referring to students' diverse academic levels. This finding was seldom addressed by previous studies and this indicates that PBL can be an appropriate solution to address the challenge of student diversity, in addition to the issue of a lack of motivation, located in the Qatari context (Said, 2016).

Regarding teachers' beliefs about their roles, the metaphor results depicted certain aspects of change that mainly took place in two categories shifting from subject matter expertise to didactical expertise, which is regarded as one of the most common beliefs reflecting constructivist views of learning for teaching (Beijaard, Verloop, \& Vermunt, 2000) after PBL implementation. This shift is aligned with the results of previous studies documenting the same direction of transformation through teachers' believed roles from subject focus to didactics priority when implementing innovative teaching strategies (Beijaard, Verloop, \& Vermunt, 2000; Dole, Bloom \& Kowalske, 2016; Liljedahl, Rolka, \& Rösken, 2007). This direction of belief change is expected and aligned with the previous studies in higher levels of education that demonstrate that in order to successfully implement PBL, it is essential for teachers to develop understanding of and belief in PBL which is embedded in constructivism and student-centered approach to teaching (Dole, Bloom \& Kowalske, 2016; Kolmos, Du, Dahms, \& Qvist, 2008; Lee, Blackwell, Drake \& Moran, 2014; Pecore, 2012; Salvin-Baden, 2003).

Previous studies suggested that teachers' beliefs about teaching and learning, and their roles affected their decisions when planning and designing activities (Mihaela \& Alina-Oana, 2015; Pajares, 1992). Although the PBL practice revealed a shift from lecture-centered to more student-centered methods, a gap was observed comparing their positive perception of PBL and perceived belief change with their actual implementation practices. Certain change was observed when comparing their lesson plans prior to and after three years of PBL implementation. These teachers included visibly more student interactive activities through team work, however, they revealed various ways of defining roles of learners and teachers in the PBL process and communicating with students. In particular, more than half of them displayed their tendency of control in defining the mathematical problems to be used in classroom, directing and guiding the classroom activities. This finding revealed that despite teachers' positive attitudes and desire to use new instructional strategies, the actual implementation can be more difficult and time-consuming (Tamim \& Grant, 2013). Comparing this to the results of previous studies on PBL in secondary (Jerzembek \& Murphy, 2013; Thomas, 2000) and higher education (Kolmos, 2012; Hmelo-Silver \& Barrows, 2006; Norman \& Schmidt, 2016), that encourage students to explore ill-structured problems from real life settings, the outcome of this study indicates that scaffolding and direct instruction may be more needed in primary education than higher levels. This also suggests that different types of problems and approaches to applying PBL in classrooms are needed for lower and upper grade of K12 education and higher education.

The discrepancy between teachers' perceived belief change and their actual practices could be attributed to the challenges they defined, including teachers' insecurity and lack of confidence, difficulty in facilitating student collaboration, structural constraints, additional workload, and the lack of peer and school support. These issues became constraints that urged teachers to adjust their practices that are distant from their beliefs. These challenges are seemingly inconsistent with studies in higher levels of education, nevertheless, they may reflect different levels and attribute for different reasons. Previous studies also identified teachers' lack of confidence (Du \& Chaaban, 2019; Kolmos, Du, Dahms, \& Qvist, 2008) and challenges of helping students to engage in team projects and problem-solving processes (Lee, Blackwell, Drake, \& Moran, 2014), which could be due to the initial experience of PBL regardless of educational levels. Nevertheless, it seems that teachers from primary education, in particular, in Qatar, may be more influenced by the institutional constraint regarding fulfilling curriculum standards and consequences of potential failure. This could be a feature of a top-down approach to change to PBL, which, compared to the often-encouraged bottom-up approach to change in higher education (Kolmos, 2012; Moesby, 2004), can be more time-consuming for teachers to become true believers and change their practices accordingly.

Assessment remains an area with tremendous struggles in PBL implementation at all educational levels in terms of reaching agreement on what to access, how to access and who should access, and whether the teachers have the skills to develop assessment tools aligning PBL goals (Lee, Blackwell, Drake, \& Moran, 2014; Salvin-Baden, 2004). Nevertheless, in the given context of the study, teachers play no active roles in defining assessment, which limits not only their practice but also their belief of successful outcome of PBL. Implementing PBL at all educational levels demands supports of institutional resources such as releasing teachers from other tasks (Mosby, 2004). Higher educational institutions may have more autonomy to change policies than schools who are obligated to follow governmental policies, which offers less flexibility regarding adjusting work hours and time schedule, and providing opportunities for teachers to collaborate (Chaaban \& Du, 2017). 
Furthermore, findings from the current study may also be related to the given context of Arab culture, that may influence teachers' beliefs and practices (Wu, Palmer, \& Field, 2011). For example, expressing options in front of others is an important skill for a PBL environment, however, female students in Middle Eastern culture may find it challenging because engaging in public discussion does not fit the traditional cultural ideology of femininity (Frambach, Driessen, Chan, \& Van der Vleuten, 2012).

Outcome of this study has a few implications. First, discrepancy between belief and practice of PBL identified in this study suggests that appropriate and sufficient professional development activities are needed (Pecore, 2013). In particular, providing teachers with opportunities to experience PBL as students would benefit their deep understanding and effective implementation (Kolmos, Du, Dahms, \& Qvist, 2008; Liljedahl, Rolka, \& Rösken, 2007). The MOEHE and schools in Qatar should further articulate policy goals and standards that facilitate studentcentered approaches for teachers. System and institutional supports such as reducing teachers' workload, providing sufficient time for students' activities during PBL sessions and for teachers' collaboration, and involving both students and teachers in defining assessment (Fullan, 2014; Mosby, 2004) will benefit long term success of educational changes.

The current study several limitations. First, results of this study remain provisional due to the small number of participants and also because PBL implement involves an ongoing change process. Second, the study focused on the teachers' perspective, although it is an important angle to study educational change (Fullan, 2014; Kolmos, 2012; Salven-Baden, 2003), other perspectives such as learners' feedbacks and outcome are also essential. This indicates that follow up research on long term change of teachers' beliefs and practices, as well as perspectives from learners and management are needed. It is also crucial to gain more knowledge about students' learning outcome and performances in PBL in the lower grades of K12 education. In addition, comparative studies of teachers' perspectives with students' perceptions, performance, and learning outcomes in PBL will provide additional knowledge about this change initiative in teaching and learning in K12.

\section{ACKNOWLEDGEMENT}

We wish to express our gratitude to all the teachers who participated in this study.

\section{REFERENCES}

Adelman, H. S., \& Taylor, L. (2007). Systemic change for school improvement. Journal of Educational and Psychological Consultation, 17(1), 55-77. https:/ / doi.org/10.1080/10474410709336590

Ahonen, E., Pyhalto, K., Pietarinen, J., \& Soini, T. (2014). Teachers' professional beliefs about their roles and the pupils' roles in the school. Teacher Development, 18(2), 177-197. https:/ / doi.org/10.1080/13664530.2014.900818

Akınoğlu, O., \& Tandoğan. R. O. (2007). Effects of problem-based active learning in science education on students' academic achievement, attitude and concept learning. Eurasia Journal of Mathematics, Science E Technology Education, 3(1), 71-81. https:// doi.org/10.12973/ ejmste/75375

Araz, G., \& Sungur, S. (2007). Effectiveness of problem-based learning on academic performance in genetics. Biochemistry and Molecular Biology Education, 35(6), 448-451. https:/ / doi.org/10.1002/ bmb.97

Asghar, A., Ellington, R., Rice, E., Johnson, F., \& Prime, G. M. (2012). Supporting STEM Education in Secondary Science Contexts. Interdisciplinary Journal of Problem-Based Learning, 6(2). https://doi.org/10.7771/15415015.1349

Bakkenes, I., Vermunt, J. D., \& Wubbels, T. (2010). Teacher learning in the context of educational innovation: Learning activities and learning outcomes of experienced teachers. Learning and Instruction, 20(6), 533-548. https:/ / doi.org/10.1016/j.learninstruc.2009.09.001

Beijaard, D., Verloop, N., \& Vermunt, J. D. (2000). Teachers' perceptions of professional identity: An exploratory study from a personal knowledge perspective. Teaching and Teacher Education, 16(7), 749-764. https:/ / doi.org/10.1016/S0742-051X(00)00023-8

Bell, S. (2010). Project-based learning for the 21st century: Skills for the future. The Clearing House, 83(2), 39-43. https://doi.org/10.1080/00098650903505415

Burridge, P., \& Carpenter, C. (2013). Expanding pedagogical horizons: A case study of teacher professional development. Australian Journal of Teacher Education, 38(9), 2. https:/ / doi.org/10.14221/ajte.2013v38n9.3

Chaaban, Y., \& Du, X. (2017). Novice teachers' job satisfaction and coping strategies: Overcoming contextual challenges at Qatari government schools. Teaching and Teacher Education, 67, 340-350. https://doi.org/10.1016/j.tate.2017.07.002 
Chen, C. H., \& Chen, C. Y. (2012). Instructional approaches on science performance, attitude and inquiry ability in a computer-supported collaborative learning environment. Turkish Online Journal of Educational TechnologyTOJET, 11(1), 113-122.

Dole, S., Bloom, L., \& Kowalske, K. (2016). Transforming Pedagogy: Changing Perspectives from Teacher-Centered to Learner- Centered. Interdisciplinary Journal of Problem-Based Learning, 10(1). https:/ / doi.org/10.7771/15415015.1538

Dole, S., Bloom, L., \& Doss, K. K. (2017). Engaged learning: Impact of PBL and PjBL with elementary and middle grade students. Interdisciplinary Journal of Problem-Based Learning, 11(2), 9. https:/ / doi.org/10.7771/15415015.1685

Drake, K. N., \& Long, D. (2009). Rebecca's in the dark: A comparative study of problem-based learning and direct instruction/experiential learning in two 4th-grade class- rooms. Journal of Elementary Science Education, 21(1), 1-16. https:/ / doi.org/10.1007/BF03174712

Du, X. \& Chaaban, Y. (2019). Teachers' readiness for a statewide change to PBL in primary education in Qatar. Manuscript submitted for publication.

Du, X., Su, L., \& Liu, J. (2013). Developing sustainability curricula using the PBL method in a Chinese context. Journal of Cleaner Production, 61, 80-88. https:/ / doi.org/10.1016/j.jclepro.2013.01.012

$\mathrm{Du}, \mathrm{X}$. (2012). A proposal of task-based PBL in Chinese teaching and learning. In Exploring task-based PBL in Chinese teaching and learning (pp. 36-61). Cambridge Scholars Press.

Ertmer, P. A., \& Simons, K. D. (2006). Jumping the PBL Implementation Hurdle: Supporting the E orts of K-12 Teachers. Interdisciplinary Journal of Problem-Based Learning, 1(1). https:/ / doi.org/10.7771/1541-5015.1005

Frambach, J. M., Driessen, E. W., Chan, L. C., \& van der Vleuten, C. P. (2012). Rethinking the globalisation of problem-based learning: How culture challenges self-directed learning. Medical Education, 46(8), 738-747. https:// doi.org/10.1111/j.1365-2923.2012.04290.x

Fullan, M. (2014). Teacher development and educational change. New York: Routledge. https://doi.org/10.4324/9781315870700

Gallagher, S. A., \& Gallagher, J. J. (2013). Using problem-based learning to explore unseen academic potential. Interdisciplinary Journal of Problem-based Learning, 7(1), 9. https:/ / doi.org/10.7771/1541-5015.1322

Gallagher, S. A., \& Stepien, W. J. (1995). Implementing problem-based learning in science classrooms. School Science and Mathematics, 95(3), 136-147. https:// doi.org/10.1111/j.1949-8594.1995.tb15748.x

Grant, M. M. (2011). Learning, Beliefs, and Products: Students' Perspectives with Project-based Learning. Interdisciplinary Journal of Problem-Based Learning, 5(2). https:/ / doi.org/10.7771/1541-5015.1254

Hmelo-Silver, C. E. (2004). Problem-based learning: What and how do students learn? Educational Psychology Review, 16(3), 235-266. https:// doi.org/10.1023/B:EDPR.0000034022.16470.f3

Hmelo-Silver, C. E., \& Barrows, H. S. (2006). Goals and Strategies of a Problem-based Learning Facilitator. Interdisciplinary Journal of Problem-Based Learning, 1(1). https:/ / doi.org/10.7771/1541-5015.1004

Jerzembek, G., \& Murphy, S. (2013). A narrative review of problem-based learning with school-ages children: Implementation and outcomes. Educational Review, 65(2), 206-218. https:/ / doi:10.1080/00131911.2012.659655

Jensen, L. (2001). Planning lessons. Teaching English as a second or foreign language, 403-413.

Kazemi, F., \& Ghoraishi, M. (2012). Comparison of problem-based learning approach and traditional teaching on attitude, misconceptions and mathematics performance of university students. Procedia-Social and Behavioral Sciences, 46, 3852-3856. https:/ / doi.org/10.1016/j.sbspro.2012.06.159

Kolmos, A. (2012). Changing the curriculum to problem-based and project-based learning. Yusof, et al. (eds), Outcome-Based Science, Technology, Engineering, and Mathematics Education: Innovative Practices, 50-61, Information Science Reference. https:/ / doi.org/10.4018/978-1-4666-1809-1.ch003

Kolmos, A., Du, X. Y., Dahms, M., \& Qvist, P. (2008). Staff development for change to problem based learning. International journal of engineering education, 24(4), 772-782.

Karaçalli, S., \& Korur, F. (2014). Effects of project-based learning on students' academic achievement, attitude, and retention of knowledge: e subject of "electricity in our lives." School Science and Mathematics, 114(5), 224-235. https://doi.org/10.1111/ssm.12071

Korthagen, F. A., Kessels, J., Koster, B., Lagerwerf, B., \& Wubbels, T. (2001). Linking practice and theory: The pedagogy of realistic teacher education. New York, NY: Routledge.

Kvale, S., \& Brinkmann, S. (2009). Interviews: Learning the craft of qualitative research. Thousand Oaks: SAGE. 
Laius, A., Kask, K., \& Rannimäe, M. (2009). Comparing outcomes from two case studies on chemistry teachers' readiness to change. Chemistry Education Research and Practice, 10(2), 142-153. https://doi.org/10.1039/B908251B

Lakoff, G., \& Johnson, M. (1980). Metaphors we live by. Chicago: University of Chicago Press.

Lam, S.-F., Cheng, R. W.-Y., \& Choy, H. C. (2010). School support and teacher motivation to implement projectbased learning. Learning and Instruction, 20(6), 487-497. https://doi.org/10.1016/j.learninstruc.2009.07.003

Lee, J. S., Blackwell, S., Drake, J., \& Moran, K. A. (2014). Taking a Leap of Faith: Redefining Teaching and Learning in Higher Education rough Project-Based Learning. Interdisciplinary Journal of Problem-Based Learning, 8(2). https:/ / doi.org/10.7771/1541-5015.1426

Leuchter, M., Saalbach, H., \& Hardy, I. (2014). Designing science learning in the first years of schooling: An intervention study with sequenced learning material on the topic of "floating and sinking." International Journal of Science Education, 36(10), 1751-1771. https:/ / doi.org/10.1080/09500693.2013.878482

Liljedahl, P., Rolka, K., \& Rösken, B. (2007). Affecting affect: The re-education preservice teachers' beliefs about mathematics and mathematics learning and teaching. In M. Strutchens \& W. Martin (Eds.), 69th NCTM Yearbook (pp. 319-330).

Liu, Y., Bui, E. N., Chang, C. H., \& Lossman, H. G. (2010). PBL-GIS in secondary geography education: Does it result in higher-order learning outcomes? Journal of Geography, 109(4), 150-158. https://doi.org/10.1080/00221341.2010.497541

Löfström, E., Poom-Valickis, K., \& Hannula, M. S. (2011). Categorisation of teacher metaphors: Manual for implementing the Beijaard, Verloop \& Vermunt teacher knowledge base model. Manual for NorBa Project, 2011, 1-11.

Löfström, E., \& Poom-Valickis, K. (2013). Beliefs about teaching: Persistent or malleable? A longitudinal study of prospective student teachers' beliefs. Teaching and Teacher Education, 35, 104-113. https:// doi.org/10.1016/j.tate.2013.06.004

Luft, J. A., \& Roehrig, G. H. (2007). Capturing science teachers' epistemological beliefs: The development of the teacher beliefs interview. Electronic Journal of Science Education, 11(2), 38-63.

Merri, J., Lee, M., Rillero, P., \& Kinach, B. M. (2017). Problem-Based Learning in K-8 Mathematics and Science Education: A Literature Review. Interdisciplinary Journal of Problem-Based Learning, 11(2).

Mihaela, V., \& Alina-Oana, B. (2015). (When) Teachers' Pedagogical Beliefs are Changing? Procedia - Social and Behavioral Sciences, 180, 1001-1006. https:/ / doi.org/10.1016/j.sbspro.2015.02.191

Moesby, E. (2004). Reflections on Making a Change towards Project Oriented and Problem-Based Learning (POPBL). World Transactions on Engineering and Technology Education, 3, 269-78.

Namey, E., Guest, G., Thairu, L., \& Johnson, L. (2008). Data reduction techniques for large qualitative data sets. In G. Guest \& K. MacQueen (Eds.), Handbook for team-based qualitative research, (pp. 137-161). Walnut Creek, CA: AltaMira Press.

Norman, G. R., \& Schmidt, H. G. (2016). Revisiting 'Effectiveness of problem-based learning curricula: theory, practice and paper darts'. Medical education, 50(8), 793-797. https:/ / doi.org/10.1111/medu.12800

Novikasari, I. (2016). The profile of mathematical knowledge for teaching and mathematical beliefs of pre-service primary teachers. International Journal of Scientific Research and Innovative Technology, 3(7), 73-92.

Pajares, M. F. (1992). Teachers' beliefs and educational research: Cleaning up a construct. Review of Educational Research, 62(3), 307-332. https:/ / doi.org/10.3102/00346543062003307

Pecore, J. L. (2013). Beyond Beliefs: Teachers Adapting Problem-based Learning to Preexisting Systems of Practice. Interdisciplinary Journal of Problem-Based Learning, 7(2). https:/ / doi.org/10.7771/1541-5015.1359

Pehkonen, E., \& Törner, G. (1999). Teachers' beliefs on mathematics teaching-Comparing different self-estimation methods: A case study (Paper). Duisberg-Essen, Germany: University of Duisburg-Essen.

Patton, M. Q. (1990). Qualitative evaluation and research methods (2nd ed.). Newbury Park, CA: Sage Publications.

Rico, R., \& Ertmer, P. A. (2015). Examining the role of the instructor in problem-centered instruction. Tech- Trends, 59(4), 96-103. https:/ / doi.org/10.1007/s11528-015-0876-4

Roh, K. H. (2003). Problem-based learning in mathematics: ERIC Digest. Columbus, OH: ERIC Clearinghouse for Science Mathematics and Environmental Education.

Sabah, S., \& Du, X. (2018). University faculty's perceptions and practices of student centered learning in Qatar: Alignment or gap?. Journal of Applied Research in Higher Education, 10(4), 514-533. https:/ / doi.org/10.1108/JARHE-11-2017-0144 
Said, Z. (2016). Science Education Reform in Qatar: Progress and Challenges. Eurasia Journal of Mathematics, Science $\mathcal{E}$ Technology Education, 12(8), 2253-2265. https:/ / doi.org/10.12973/eurasia.2016.1301a

Savin-Baden, M. (2004). Understanding the impact of assessment on students in problem-based learning. Innovations in Education and Teaching International, 41(2), 221-233. https:/ / doi.org/10.1080/1470329042000208729

Savin-Baden, M. (2003). Facilitating problem-based learning: Illuminating perspectives. Maidenhead, England: Open University Press.

Savery, J. R. (2006). Overview of problem-based learning: Definitions and distinctions. The Interdisciplinary Journal of Problem-Based Learning, 1(1), 9-20. https:/ / doi.org/10.7771/1541-5015.1002

Schettino, C. (2016). A Framework for Problem-Based Learning: Teaching Mathematics with a Relational ProblemBased Pedagogy. Interdisciplinary Journal of Problem-Based Learning, 10(2). https://doi.org/10.7771/15415015.1602

Schoenfeld, A. H. (1998). Toward a theory of teaching-in-context. Issues in Education, 4(1), 1-94. https:/ / doi.org/10.1016/S1080-9724(99)80076-7

Sungar, S., \& Tekkaya, C. (2006). Effects of problem-based learning and traditional instruction on self-regulated learning. The Journal of Educational Research, 99(5), 307-318. https:/ / doi.org/10.3200/JOER.99.5.307-320

Talmy, S. (2010). Qualitative interviews in applied linguistics from research instrument to social practice. Annual Review of Applied Linguistics, 30, 128-48. https:/ / doi.org/10.1017/S0267190510000085

Tamim, S. R., \& Grant, M. M. (2013). Definitions and Uses: Case Study of Teachers Implementing Project-based Learning. Interdisciplinary Journal of Problem-Based Learning, 7(2). https:/ / doi.org/10.7771/1541-5015.1323

Tomas, J. W. (2000). A review of research on project-based learning. Report prepared for e Autodesk Foundation. http:/ / www.bie.org/index.php/site/RE/pbl_research/29

Wang, L., \& Du, X. (2016). Chinese language teachers' beliefs about their roles in the Danish context. System, 61, 111. https:/ / doi.org/10.1016/j.system.2016.06.009

Wong, K. K. H., \& Day, J. R. (2009). A comparative study of problem-based and lecture-based learning in junior secondary school science. Research in Science Education, 39(5), 625-642. https:/ / doi.org/10.1007/s11165-0089096-7

\section{http://www.ejmste.com}

